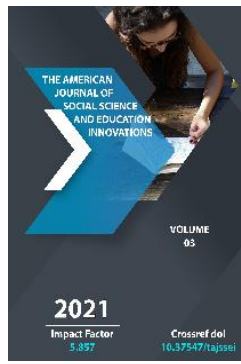

\title{
The Fantastic Elements In The Image Of Spirit As An Artist
}

\author{
Dilmurov Khaydaralievich Kuronov \\ Doctor Of Philological Sciences, Professor Of Andizhan State University, Andizhan Region, \\ Republic Of Uzbekistan
}

Nurmuhammad Nematullaevich Azizov

Doctorate Of Andizhan State University, Andizhan Region, Republic Of Uzbekistan

Journal Website:

http://usajournalshub.c

om/index,php/tajssei

Copyright: Original

content from this work

may be used under the

terms of the creative

commons attributes

4.0 licence.

\section{ABSTRACT}

The article explores the norealistic elements used as a poetic tool in illuminating the protagonist's psyche. In particular, the problem of artistic psychologism was seriously studied through the analysis of the image of a driverless bus in the novel "A Thousand and One Images" (Ming bir qiyofa) and the motives of the characters to change places with the demands of the situation.

\section{KEYWORDS}

Artistic psychologism, animal motive, artistic conditionality, realistic and unrealistic element, the motive of the characters to change places with the demands of the situation.

\section{INTRODUCTION}

It is known that in order for the image of a person in a work of art to be fully embodied in the eyes of the reader, it is necessary to describe his image along with his image. The importance of artistic psychology in an epic work is first and foremost determined by this. The processes that take place in the inner world of the character, the depiction of his 
thoughts and feelings, the psychological justification of his actions and speech - all this is understood as artistic psychologism. There are various means of depicting and analyzing the psyche of a character, and psychological justification. In this article, we focus on the non-realistic elements used as such a tool, and consider their artistic functions in the example of the driverless bus image in the novel " $A$ Thousand and One Images" and the motives of the characters to change places with the demands of the situation.

\section{METHODS}

Entering the character's psyche, first of all, helps to get acquainted with the spiritual state of the author in the moments of creation, the influence of society on the creator and the attitude of the creator to society. This, in turn, requires the interpretation of the abovementioned poetic elements in context, that is, taking into account the conditions of the period in which the work was created and based on them. In other words, in order to achieve the desired goal, it is necessary to approach the listed elements only from the point of view of pure poetics, to use the possibilities of the sociological method, to think based on it.

\section{RESULTS AND DISCUSSIONS}

The first story of the novel "A Thousand and One Images" begins with a realistic image - the scene of the protagonist's sudden return from the party. Not to mention the driverless bus that suddenly appeared, there is no other image in the first story that contradicts the reality of life. Its sleek shape, sturdy hoods, and soft seats give it a fantastic look, but it's also fantastic to drive without a driver. The author describes the situation of the protagonist when he saw the same scene: "The other person could have lost his temper and put ayyuhannos in such conditions. He was a very calm person by nature, he didn't let the world down, and he was in a good mood" [4.p.11]. The situation in which Abdullah Hakim fell is a fantastic situation that introduces us closely to the character traits of the image. The characterization given by the author in the first moments when the protagonist gets on the bus is confirmed by his behavior during the events, as well as the accusation of the angels, "You were in the stream, wherever the stream led, you would go".

Literary critic E. Voloshchuk believes that "in the image of the railway there is the idea of man's freedom, his subordination to a hidden force in the depths of technology" [6.p.80]. Indeed, it is. It is common to interpret a train and a tram as a symbol of human freedom, which is forced to follow only a certain path. The bus in Omon Mukhtor's novel semantically forms a hive with a train motif, both of which take people from one place to another as a vehicle. In this sense, both the bus and the train should be considered options for a single invariant motive. However, the genesis of the "bus" in the novel Omon Mukhtor is not a beast at all, but a motive of a beast that deprives man of his freedom and subdues his desires. Such a motif has a very ancient historical genesis in the art of speech: a witch (winged horse) or a flying carpet due to the forgetfulness of the word talisman: a chariot that escapes control in the Indian epic or a vulture that escapes under the influence of a rider. Also included are the "sledge" and "chase" in H.K. Andersen's famous fairy tales "Snow Queen" and "Red Bucket". One (sledge) takes the character to another, unknown place, despite his resistance, while the other ("chase") forces the protagonist to dance 
involuntarily. In the novel we are examining, the power of technology and the issue of human freedom are fantastically portrayed as driving a bus without a driver. Initially, the protagonist's voluntary adaptation to the environment on the bus was due to his calmness, drunkenness, and the fact that the car was going on a familiar road. we see the desire for freedom as the force that drives the image. No matter how hard Abdullah Hakim tries to control the bus and try to regain his freedom, he has no choice but to "be amazed at the madness of a sticky car driven from another place." The fact that the car blocked Abdullah Hakim and brought him to the front of the White-and-Red building means that the destruction of the protagonist, the technical motive, serves evil. It should be noted that, unlike realistic works depicting motifs such as trains and trams, the fact that the bus is driverless has an important aesthetic purpose. If the image of the driver was depicted in the incident, the protagonist would first come into conflict with the human factor, leaving the supernatural force dominating the bus in the shadows. In addition, the driverless bus is the first step of the author, who has previously written traditional realistic works, into the world of fantasy, as well as the fact that Abdullah Hakim "has more strange events ahead" and "emotionally and intellectually to urge the reader to accept them" [2.p.23] was a tool in preparation. As expected, in the subsequent scenes of the first story, fiction and fantasy rise to the forefront.

Literary critic Sh. Daniyarova writes about the first scene in the novel "A Thousand and One Faces" - "Prisoner", in which the story and the actions of the protagonist are unbelievably expressed. It is clear from the text that the phrase "unbelievably expressed" refers to
Abdullah Hakim's condition on the bus, and we have mentioned above that this is evidenced by the character's personality traits, as well as his drunkenness. The fact that the bus is driverless is a magical motif in folklore, a supernatural phenomenon in fiction, and, most importantly, a fantastic detail, a symbol that serves the realization of the author's ideological and artistic intentions. In our opinion, Sh. Daniyarova does not seem to pay enough attention to the symbolic scale of the image, which is why she seeks a vital basis for the bus without a driver: "In the age of science and technology, a man can easily drive a spacecraft without a driver! It is also an imaginary tissue that can be realized in the future." [7].

It should be noted that the prediction of a future event in the interpretation of Sh. Daniyorova is typical of science fiction, in this type of science fiction will happen because of [1.p.344]. Here it would be correct to look at the bus only as a means of artistic conditionality. Professor Kazakboy Yuldashev says that the fantasy conditionality in the work of art is intended to elevate the event depicted to a level that does not fit into formal logic in order to push it beyond its logical boundaries. A number of methods of fantastic conditionality include alogism (irrationality), in which the violation of the logical sequence in the cause-and-effect relationship in real life, the impossibility of rational interpretation of the event, the nature of the irrational event or hero, the nature of irrational characters or emphasizes that it serves to reveal the meaning of the life event depicted [3.p.204]. The novel "A Thousand and One Appearances" is one of the novels in which this method is used effectively. Apparently, the driverless bus in the novel is merely an artistic tool, as an aid 
in the interpretation of a realistic problem. We think that a driverless bus is a symbol of destiny created by the creative imagination, and it is not up to the gang to escape from it or turn to the other side. If we approach the issue with the above views, the assessment of Sh. Doniyorova's interpretation as "unreliable" does not justify itself.

It is known that the motif is taken in a semifinished form, the existing motifs are not exactly, but are interpreted in different variants depending on the ability of the writer's artistic imagination and creative intention, while preserving the core [1.p.180]. The motive of the protagonists to change places with the demands of the situation is found in both folklore and fiction, and plays an important artistic and aesthetic function in the implementation of ideological and artistic intentions.

Although Askad Mukhtor's Chinor and Omon Mukhtor's A Thousand and One Faces differ significantly in terms of subject matter and artistic problem, the story of the protagonist's death, Akbarali and Burhan Sharif's state of mind at the head of "his own grave," and selfexamination in the course of events. the issue of past thoughts, personality tragedy, and spiritual crisis will form the basis for a comparative study of the two images. (It should be noted that although Akbarali is associated with Burhan Sharif, a comparative study of his pre-election situation with Abdullah Hakim and his experiences with Burhan Sharif is more effective in revealing the psyche of the image).

In both novels, the deceased character is buried under a different name, which ultimately becomes the optimal option for the realization of the author's artistic intent, a true depiction of the psychological state of the character, the intensification of internal conflict, as well as emotional impact on the reader.

The change of characters in "A Thousand and One Images" differs from the motif in the novel "Plane" in that it takes place before the fact of death. In the novel Omon Mukhtor, a fantastic character in the emergence of this motif - a driverless bus acts as a vehicle. Because of the similarity in appearance, businessmen tortured Abdullah Hakim instead of Burhan Sharif. The character does not introduce himself in order to get out of a difficult situation by first using the power and prestige of another:

- Yes, I am Burhan Sharif. No one has the right to treat me like that [4.p.15].

When Abdullah Hakim fails to survive the evils of introducing himself as Burhan Sharif, he is faced with the choice of either introducing himself and telling the truth or remaining as Burhan Sharif to the end. The protagonist, who blindly continued the misunderstanding that arose for the first time, chooses the second way in the contest as well, and now he becomes Burhan Sharif not only on the outside but also on the inside.

"I don't need anything from you," he said calmly. Then Burhan Sharif added: "I have not learned to take alms from anyone, nor to do haram." [4.p.22]

First of all, it should be noted that the presence of the human factor in the contest against Abdullah Hakim, the protagonist has ample opportunity to think. In contrast, the fate of the contest against Akbarali in "Chinor" is divine, he has only a moment or two to make a decision. This is also the sharp drama in the character's psyche. Furthermore, the survival 
of Akbarali and the death of Abdullah Hakim is the most acceptable way to fulfill the artistic intention. Since Chinor is a realistic work, the events in it are similar to real life. That is, when Bektemir is buried, he continues to live in Akbarali's thoughts, revealing his psychological state, complex contradictions in his psyche. This is in fact the poetic task assigned to the image of Bektemir. The nonrealist work "A Thousand and One Images" does not stop his participation in the plot even after the death of Abdullah Hakim, which allows the author to predict the fate of sinners, convincingly portray the doomsday and the torments of hell, to show the future of a thousand different faces.

There are also commonalities in the details chosen to prove the motives of the protagonists to change places with the demands of the situation. In Chinor, Bektemir is known as Akbarali by Shodasay residents, and in Omon Mukhtor, he is beaten, his face is looted by bees, and he is killed by his invitations and testimonies, causes him to become another person. The fact that Burhan Sharif's wife and children did not recognize that the deceased was a different person is explained by the main idea of the novel - disguise. This means that the motif was creatively reworked by Omon Mukhtor and directed towards his artistic goal.

As the exchange of Oman Mukhtar's heroes unfolds in the reader's mind, the human qualities of Burhan Sharif's character give him hope that he will restore the name of Abdullah Hakim. When the truth came out, he said to the grave, "Abdullah Hakim. The Poet and the Man "saves Burhan Sharif from the pangs of conscience, albeit partially. "I promised Abdullah Hakim, standing at his grave, with tears in my eyes, that I would restore your name. It was a real oath then! I, of course, soon installed a marble stone on his grave. I engraved his name. In this way, I was able to remain calm, as if I had done my duty to the person who gave his life for me." [4.p.161] From this speech in an interview with Sadirjon, we understand that Burhan Sharif himself was primarily interested in this movement, and that restoring the truth was a way for him to find peace of mind. During the conversation, Abdullah Hakim was told that a marble stone, a beautiful sagan, a horse-shaped monument none of this is important, it is important to him what he wrote during and after his life, it is the tragedy of Burhan Sharif, who hid the real poet while restoring his name.

The culmination of the story is the fact that Akbarali accidentally encounters his own grave (actually Bektemir's grave) in the cemetery, a surprise for both the protagonist and the reader. In this case, Akbarali is given a second chance to restore the truth. In the period from the city to Shodasay, the hero, who lost his human form due to mental anguish, faced a spiritual decline and became a creature, was also overcome in this test, which was in line with the logic of nature and work. If the psyche of the image is studied before the truth and in the face of reality, it becomes clear that he looked at work, alcohol and even love as a means of forgetting horror, hunting, as a person in the process, and after the truth he had no encouragement or consolation in life. "Fever! No, I'm not crazy! It's a fever! Cold fever! "I don't think so." Bektemir, my mother, Hadiya, myself ... Myself? Am I in the cemetery? Yes, yes, I don't think so, I don't think so. " [5.p.259].

The fact that Achil Baba came to Shodasay with full confidence after the missing Akbarali was boiling at the bottom of the cliff is the true end 
of the hero's destiny. As mentioned in the epigraph, the fact that the most terrifying beast is a rabbit has become a real artistic reality in the example of Akbarali's image.

Abdullah Hakim's courage and devotion to a friend ended in physical death, while Akbarali's inability to overcome instantaneous fear ended in mental death. The parable of Achil Bobo in his speech about Bektemir, "For some, a dead man is alive," is essentially a bright line for Abdullah Hakim.

The motive of the protagonists to change places with the demands of the situation allows to develop the plot, to explore the reality through different perspectives, to increase the emotionality in the image. It is safe to say that Askad Mukhtor and Omon Mukhtor used this motif to look at the root of the problems in the social environment and to fully cover the changes in the psyche and the tragedy of the individual.

\section{CONCLUSION}

Undoubtedly, the novel Omon Mukhtor from the compared works is the product of the next stage in our national artistic thinking. That is why it has a serious departure from traditional realism. At the same time, the novel " $A$ Thousand and One Images" is closely related to the period in which it was created and the social environment of this period - a work about real life, real people in real life, their unique destinies and actions. The realistic and non-realistic elements in the novel are so naturally combined that with this feature the novel opened the way to new image principles in our prose, bridging the gap between our traditional and non-traditional prose.

\section{REFERENCES}

1. Quronov D, Sheralieva M, Mamajonov Z. Dictionary of Literary Studies. Tashkent: Akademnashr, 2013. - 406 p.

2. Quronov D. Literary Thoughts. Tashkent: Turon zamin ziyo, 2016. - 110 p.

3. Yuldashev Q. Fundamentals of artistic analysis. - Tashkent: Kamalak, 2016. $306 \mathrm{p}$.

4. Mukhtor O. A Thousand and One Images // In the book: Mukhtor O. To'rt tomon qibla. - Tashkent: Sharq, 2000. p. $11-162$.

5. Mukhtor A. Chinor. - Tashkent: Yangi asr avlodi, 2018. - $576 \mathrm{p}$.

6. Voloschuk. E. This is how we got lost (The artistic reality of F. Kafka's parable "Railway passengers" in the context of the development of the anthropocentric paradigm) Vikno in retinue. 1998. No. 2. p. 62-97. Doniyorova Sh. New interpretations. [Internet resource]. URL: https://saviya.uz. (Date of application: 01.02.2021) 